\title{
Science teacher education in Japan: past, present, and future
}

Tetsuo Isozaki(i)

\author{
Correspondence: \\ isozaki@hiroshima-u.ac.jp \\ Hiroshima University, Graduate \\ School of Education, \\ Higashi-Hiroshima, Hiroshima, Japan
}

\begin{abstract}
The purpose of this paper is to describe the historical development of science teacher education in pre-service and in-service education in Japan with a focus on the systemic changes and teachers' professional learning culture. The characteristics of science teacher education generally are elucidated through an analysis of the system and professional culture across time in Japan. There is a conflict regarding the integration and balance between pedagogical and content knowledge across the world. The author identified this problem as a historical and socio-cultural aporia regarding the ideal model of secondary school science teachers. In the study's conclusion, the author argues, based on the historical and international perspectives, that we should not ignore science teachers' traditionally accumulated wisdom and expertise, and that it is critical to identify the role that the professional learning community plays role in aiding prospective teachers to become expert science teachers.
\end{abstract}

Keywords: Science teacher education, Teacher knowledge, Professional culture, Professionalism, Academism

\section{Introduction}

Some international surveys - such as the Trends in International Mathematics and Science Study (TIMSS), and the Programme for International Student Assessment (PISA), conducted in 2015, as well as the Teaching and Learning International Survey (TALIS), carried out in 2013 - have successfully portrayed Japan's educational system and the features of Japanese teachers' professional/occupational culture (hereinafter referred to as professional culture), as well as students' higher academic achievement. For example, Green (1997) pointed out that professional culture "exists as a historical sediment, visible in the cultural norms and institutional practices of the learning society" (p. 297). Japan began to develop its professional learning culture with advent of modernization in the second half of the nineteenth century.

In Japanese, the term "teacher" is complex because it can be expressed by three words. Kyoshi (kyōshi) might be the closest word to the English meaning of "teacher" (Isozaki, 2016). Debates about the models that describe teachers and their professional culture have existed since the late nineteenth century (e.g., Kimura \& Iwata, 2007; Kumura \& Iwahashi, 1967 Shimahara, 1998). However, the meaning of "profession" might not exactly correlate with the Western concept of it (Kimura \& Iwata, 2007).

(C) The Author(s). 2018 Open Access This article is distributed under the terms of the Creative Commons Attribution 4.0 International License (http://creativecommons.org/licenses/by/4.0/), which permits unrestricted use, distribution, and reproduction in any medium, provided you give appropriate credit to the original author(s) and the source, provide a link to the Creative Commons license, and indicate if changes were made. 
These facts reflect on and exemplify teachers' professional culture in Japan, which differs from that of Western countries.

Looking at pre-service teacher education among 4th and 8th-grade teachers in Hong Kong, Singapore, South Korea, Taiwan, and Japan, Japan has the lowest percentage of teachers that hold master's degrees (IEA, 2016). This means that teacher education/training in Japan has remained at the bachelor's degree level since the teacher education system was reformed in 1949, despite that some Asian - as well as Western - countries have been moving toward the standardization of teacher education in graduate schools. These findings indicate that in Japan's professional culture, teachers have traditionally contributed to students' good performance, although pre-service teacher education has not caught up to the rest of the world.

This paper aims to describe the historical development of teacher education in Japan, with a focus on its system and professional culture, by exploring the case of science teachers. The paper further identifies and describes the characteristics of Japanese teacher education, both in pre-service and in-service education. This paper covers problems that arose between the mid-nineteenth century and WWII, as well as between the post-WWII period and the advent of the twenty-first century, and from 2000 until the present. Based on the analytical results, future challenges are discussed concerning teacher knowledge.

\section{Teacher education from modernization until world war II (WWII)} The organization of teacher education and the antagonism between two models of it

After the Meiji Restoration in 1868, the government introduced public education, which included teacher education based on the Western - particularly German, French, and American - models, since these were considered advanced. Compared to other Western countries, the American influence on teacher education was as follows. First, the new Japanese government introduced well-paid oyatoi-gaikokujin, employed foreign advisors brought by the government; examples include Marion McCarrell Scott (1843-1922), a professor at Tokyo Normal School, who introduced the Western teaching methods. He stated that "Yet the manner and matter were all changed... They have substituted our system of figures for theirs in all their schools" (Scott, 1884, p. 256). It seems that he believed in the overwhelming Western, particularly American influence on the Japanese modern education including teacher education. Second, based on advice from the oyatoi-gaikokujin, the government sent students to the US to study, such as Shuji Isawa (1851-1917) and Hideo Takamine (1854-1910), who explored pedagogy based on Johan H. Pestalozzi's (1746-1827) philosophy and teacher education. When they returned to Japan, they effectively contributed to the organization of teacher education and disseminated Pestalozzian teaching methods, such as the object lesson.

The Normal School Order of 1886 reformed the normal school system under the strong leadership of the first Minister of Education, Arinori Mori (1847-1889). Normal schools had two levels: ordinary and higher normal schools. One higher normal school was founded in Tokyo (another was established in Hiroshima in 1902) and directly placed under the administration of the Ministry of Education. Further, normal schools were opened in every prefecture. Normal schools educated the principals and teachers of public elementary schools in each prefecture, whereas Tokyo Higher Normal School 
educated the head teachers and teachers of ordinary normal schools with secondary school status. According to the Normal Education Order of 1897, Tokyo Higher Normal School was responsible for educating teachers in all secondary schools (Ministry of Education, 1980). The normal and higher normal schools had two important roles. First, normal schools were prefectural educational centers for research and practice, whereas higher normal schools were hubs for national educational research. Second, normal schools offered in-service teacher education programs for unqualified teachers (Sato, 1999) and some activities for teachers, such as open-house lesson study (Isozaki \& Isozaki, 2011; Isozaki, 2015), editing secondary school textbooks, and publishing educational periodicals.

Further, normal schools had elementary schools attached to them, while higher normal schools had both elementary and secondary schools. These attached schools functioned in three important ways: as (1) experimental schools for research and practice, (2) venues of teaching practice for students, and (3) model schools for local areas (Isozaki, 2015:2017). Tokyo and Hiroshima's higher normal schools had several science and non-science departments. Science departments comprised mathematics, physical sciences, and natural history courses. Subjects, such as ethics and morality, pedagogy and psychology, and Japanese and English, were compulsory in every department, along with teaching practices in the attached elementary and secondary schools. Notably, the Normal School Order of 1886 stressed that students develop "a good and obedient, faithful, and respectful character" (Ministry of Education, 1980, p. 131).

Due to Mori's educational reforms, the Pestalozzian influence from the US yielded to the Herbartian five-step educational philosophy of teaching created by Wilhelm Rein (1847-1929). The influence of German pedagogy into Japan began when German professor Emil Hausknecht (1853-1927), one of the oyatoi-gaikokujin, gave a lecture at the Imperial University (later re-named the University of Tokyo) in 1887. From that point in time until the 1910s, rika (science education) (Ogawa, 2015) was more influenced by German educational philosophy and teaching methods than those of the UK and US.

Three groups (embracing Western, Confucian, and nationalist positions) engaged in ideological conflicts over educational initiatives from the time of the Meiji Restoration to the end of the nineteenth century. The conservative reaction reached its zenith with the promulgation of the Imperial Rescript on Education in 1890 (e.g., Isozaki, 2014; Sansom, 1968). However, Ferguson (1985) observed that Japanese education was more interested "in keeping the tenets of Confucianism and traditional Japanese culture than with those underlying Western pedagogical thought" (p. 22). For example, Japan's rika was influenced by Western countries' educational philosophy and teaching methods, although the term "recontextualization" (Isozaki, 2014) has retained the key word shizen (nature) since the late nineteenth century.

\section{The antagonism between professionalism and academism}

The Japanese government organized teacher education during the nineteenth century. Inoue (1975) evaluated the organization of teacher education in two parts: (1) teachers were regarded as professionals and (2) trained at professional schools. However, the latter part only applied to elementary school teachers and partially to secondary school 
teachers. While only graduates from normal schools could become elementary school teachers, university and college graduates (as well as higher normal school graduates) could become secondary school teachers due to the different forms of education that higher normal schools offered. This dual system created antagonism between teachers who graduated from each system (Isozaki, 2016; Miyoshi, 1979). While the Imperial University had the "goal [of] the teaching of, and [conducting] the fundamental research into, arts and sciences necessary for the state" (Ministry of Education, 1980, p. 121), higher normal schools aimed to educate secondary school teachers. These schools' curricula reflected their functions, while the Imperial University focused on research in the sciences, and did not offer courses on professional studies for becoming a secondary school science teacher. In contrast, higher normal schools stressed professional studies involving teaching practice in their attached schools.

Normal and higher normal schools tended to organize separate alumni associations. These associations provided professional learning communities for their graduates by publishing bulletins in which ideas and information on education were shared. Publishing books and periodicals on education is an important and common tradition in Japan's professional culture. The model of education for teachers who graduated from normal and higher normal schools centered on professionalism; however, it was criticized for not focusing on deep content/subject matter knowledge, and "normal school types" were criticized for "hypocrisy, formalism, inadaptability and indecision" (Kumura \& Iwahashi, 1967, p. 82). In contrast, the model of education for teachers who graduated from universities was based on academism, which was criticized for not focusing on pedagogical knowledge and teaching competencies acquired through professional studies. Miyoshi (1979) argued that this antagonism between the two sectors was "partly due to school nepotism among graduates, which has been an obstacle to resolving disputes about the teaching profession" (p. 29). More importantly, the antagonism between the two models of teacher education (professionalism and academism) is still reflected in the current model for secondary school teachers.

\section{In-service teacher education before WWII and the emergence of professional culture}

Unlike the post-WWII period, the Ministry of Education did not systematically organize in-service teacher education before the war. Earlier, opportunities for in-service teacher education were mostly provided through the following programs: (1) prefectural normal schools and the elementary schools attached to them; (2) local and pan-Japanese learned academic societies, as well as other organizations; and (3) teachers' self-improvement/study (e.g., reading books, participating in lesson study, or engaging in other voluntary educational activities). Thus, prefectural normal schools provided in-service teacher education programs for unqualified teachers as well as pre-service teacher education, and normal schools with schools attached to them had seminars and open-house lesson study as part of in-service teacher education programs. Tokyo Higher Normal School provided special courses to inspectors at the request of the Ministry of Education in 1905; it also offered in-service teacher education programs in the form of subject-matter courses (lasting 4 or 5 weeks) for secondary school teachers every year starting in 1909 (Tokyo University of Arts and Sciences, 1931). 
The learned societies involving academics and voluntary educational organizations provided teachers with learning opportunities. The pan-Japanese learned societies, established by teachers for science teaching, date back to 1918 for elementary school teachers and 1926 for secondary school physics and chemistry teachers. The activities of pre-WWII societies were similar to those of current academic associations, including discussions and advisement on matters brought forth by submitting proposals to the Ministry of Education (Isozaki, 2016). Most of the learned societies offered teachers four types of learning opportunities: (1) annual meetings to present research results, information and knowledge exchanges, and discussions on teaching science and other educational issues; (2) editing and publishing periodicals and books comprising academic and practice-based papers, written by teachers and researchers; (3) special lectures delivered by scientists, practitioners, school inspectors or senior specialists from the Ministry of Education; and (4) practical activities, such as lesson study (Isozaki, 2016). These activities have encouraged a culture of expert collaboration throughout the wide range of professional communities.

Oshima (1920) proposed three prerequisites for successful science teaching: (1) adequate facilities; (2) a thorough system of regulations and orders; and (3) well-educated teachers. He strongly argued that the last item was particularly important because, without enthusiastic and knowledgeable teachers, the benefits of quality facilities and an established system could not be realized. His views emphasize how teachers' self-improvement is important for effective science teaching. He also asserted that science teachers need to have deep insight into science education and should work in accordance with the higher ideals of the teaching profession. For this, they should have sufficient knowledge regarding the nature of science as well as scientific principles, understand the development of science teaching associated with the history of science, and should research the nature of science education from a wide range of educational perspectives. Although his philosophy is about one hundred years old, it never seems dated, and affirms that science teachers should consider science teaching from angles of both science and pedagogy. Even today, there is something to learn from his philosophy. In terms of effective science teachers, his views offer some points for discussion on the knowledge that prospective teachers should acquire in the pre-service program and develop in the in-service program.

\section{Teacher education after WWII until the end of the twentieth century The reorganization of teacher education system}

The current teacher education system came into being in 1949 through the Educational Personnel Certificate Law/Act. This law was based on recommendations from the United States Education Mission to Japan during the Occupation Period (1945-1952). Normal and higher normal schools were abolished, and two principles for teacher education were established that have existed since WWII: (1) teacher education at universities; and (2) an open teacher certificate system for licensure (hereinafter referred to as the open system) (e.g., Isozaki \& Ochi, 2017; Miyoshi, 1979).

Teacher education at universities mandates that teachers graduate from four-year-courses at universities that have been accredited by the Ministry of Education as teacher education institutions. Therefore, in Japan, a bachelor's degree is the basic 
qualification for obtaining a certificate to teach kindergarten through upper secondary school (grades 10-12). Prospective teachers must take three courses of study at the university level: general education for liberal arts, professional studies, and a teaching subject specialty (e.g., science or mathematics). The open system means that all university faculties and teacher education universities accredited by the Ministry of Education receive equal treatment under the Educational Personnel Certificate Law, regardless of national or private status, with educational or other faculties. Moreover, accredited universities can offer a variety of teacher certificates to accommodate newly implemented six-year elementary school, three-year lower secondary school, and three-year upper secondary school systems. These principles of teacher education may have contributed to the serious shortage of qualified teachers at the inception of the new system, and produced teachers who were motivated to work hard and develop professionally. However, some problems remain unsolved. For example, many prospective teachers as a student teacher must take compulsory teaching practice in schools as part of their professional studies, but few become teachers, and issuing teacher certificates becomes an "easy-going way" (Tokuhiro, 1970, p. 142) for some institutions to attract students, which has spoiled the prestige of teaching.

Since the end of WWII, two types of teacher education institutions -Type A and Type B -have existed that are similar to those found before WWII. In Type A, educational faculties at universities or teacher education universities educate prospective teachers based on former professionalism. In Type B, non-educational faculties at universities educate prospective teachers based on former academism. Type A institutions originated in the pre-WWII system of prefectural normal and higher normal schools. The prefectural normal schools transformed into educational faculties at national universities or national teacher education universities. The primary goal of educational faculties at these universities and teacher education universities has been to educate prospective teachers for the levels of kindergarten through upper secondary school. Conversely, non-educational faculties at universities (e.g., faculties of science or engineering) have offered optional courses for teacher certificates, but their students are not necessarily required to obtain a teacher certificate. What are the differences between Type A and Type B?

The Education Personnel Certificate Law and other regulations set forth the general guidelines, policies, and minimum numbers of credits needed to obtain a teacher certificate (Tables 1 and 2). Therefore, the specific criteria of certificates depend on the individual teacher education institution. To become a teacher at a Type A or Type B institution, a student must take general courses in liberal arts including the Constitution of Japan, physical education, foreign language communication, and the use of information devices. However, there are significant differences between the two types with regard to professional studies and teaching subject specialties. Type A institutions generally offer a variety of teacher certificates from kindergarten through upper secondary school that cover a wide range of subjects for lower and upper secondary schools (grades 7-9), such as science and mathematics. Because Type A institutions have adequate human resources, they offer professional studies covering a broad range of subjects such as pedagogy, psychology, and subject didactics. In addition, Type A institutions have effective facilities, such as attached schools for teaching practice. Type A institutions generally have robust relationships with the prefectural and municipal boards of education. 
Table 1 The minimum number of credits of teaching subject specialties and professional studies for a teacher certificate

\begin{tabular}{|c|c|c|c|c|}
\hline Year & $\begin{array}{l}\text { Certificate of basic qualification: } \\
\text { bachelor's degree }\end{array}$ & $\begin{array}{l}\text { Teaching subject } \\
\text { specialties (science) }\end{array}$ & $\begin{array}{l}\text { Professional } \\
\text { studies }\left(^{*}\right)\end{array}$ & $\begin{array}{l}\text { Teaching subject } \\
\text { specialties or } \\
\text { professional studies }\end{array}$ \\
\hline \multirow[t]{2}{*}{ 1949 } & Lower secondary school & 30 & 20 & - \\
\hline & Upper secondary school & 30 & 20 & - \\
\hline \multirow[t]{2}{*}{$1954 \sim$} & Lower secondary school & 40 & 14 & - \\
\hline & Upper secondary school & 40 & 14 & - \\
\hline \multirow[t]{2}{*}{ 1988 } & Lower secondary school & 40 & 19 & - \\
\hline & Upper secondary school & 40 & 19 & - \\
\hline \multirow[t]{2}{*}{ 1998 } & Lower secondary school & 20 & 31 & 8 \\
\hline & Upper secondary school & 20 & 23 & 16 \\
\hline \multirow[t]{2}{*}{ 2019 } & Lower secondary school & 59 & & - \\
\hline & Upper secondary school & 59 & & _- \\
\hline
\end{tabular}

Note: Asterisk $\left.{ }^{*}\right)$ shows that the details of contents are shown in Table 2 (Sources: Watanabe, 2012; Ministry of Education, 2017)

On the other hand, Type B institutions offer fewer teacher certificates (e.g., only the elementary school teacher certificate, or only ones for science in lower and upper secondary schools); in addition, they generally emphasize teaching subject specialties rather than professional studies. Because the main goal of Type B institutions is to engage in academic research and educate specialists in the field, a teacher certificate is

Table 2 The minimum requirement of professional studies since 1998

\begin{tabular}{|c|c|c|c|}
\hline Subjects & Contents of subjects & $\begin{array}{l}\text { Lower } \\
\text { secondary }\end{array}$ & $\begin{array}{l}\text { Upper } \\
\text { secondary }\end{array}$ \\
\hline \multirow[t]{3}{*}{$\begin{array}{l}\text { Subjects related to significance } \\
\text { and nature of teaching profession }\end{array}$} & $\begin{array}{l}\text { The significance and nature of teaching } \\
\text { profession, and the role of teachers }\end{array}$ & \multirow{3}{*}{2} & \multirow{3}{*}{2} \\
\hline & Job specifications of the teacher & & \\
\hline & Providing opportunities of career decision & & \\
\hline \multirow[t]{3}{*}{$\begin{array}{l}\text { Subjects related to basic theories } \\
\text { of education }\end{array}$} & $\begin{array}{l}\text { Ideas of education, history and thought of } \\
\text { education }\end{array}$ & \multirow{3}{*}{6} & \multirow{3}{*}{6} \\
\hline & $\begin{array}{l}\text { Mental and physical development, and } \\
\text { learning process of children }\end{array}$ & & \\
\hline & $\begin{array}{l}\text { Social, institutional, and managerial affairs of } \\
\text { education }\end{array}$ & & \\
\hline \multirow[t]{5}{*}{$\begin{array}{l}\text { Subjects related to curriculum } \\
\text { and teaching methods }\end{array}$} & $\begin{array}{l}\text { The significance of curriculum and methods } \\
\text { of its organizing }\end{array}$ & \multirow{5}{*}{12} & \multirow{5}{*}{6} \\
\hline & Methods of subject teaching & & \\
\hline & Methods of moral education & & \\
\hline & Methods of special activities & & \\
\hline & $\begin{array}{l}\text { Methods of education and technique } \\
\text { including ICT }\end{array}$ & & \\
\hline \multirow{5}{*}{$\begin{array}{l}\text { Subjects related to student guidance, } \\
\text { educational counseling, and } \\
\text { career guidance }\end{array}$} & Theories and methods of student guidance & \multirow{3}{*}{4} & \multirow{3}{*}{4} \\
\hline & $\begin{array}{l}\text { Theories and methods of educational } \\
\text { counseling }\end{array}$ & & \\
\hline & Theories and methods of career guidance & & \\
\hline & Teaching practice & 5 & 3 \\
\hline & Seminar in teaching profession* & 2 & 2 \\
\hline
\end{tabular}


optional. Type B institutions tend to offer the minimum amount of professional studies needed to obtain a teacher certificate. Many faculty members at Type B institutions who teach prospective teachers were trained as researchers, and may or may not have had the minimum required amount of professional studies. According to Ogawa (2014), more than $75 \%$ of upper secondary school science teachers graduated from Type B institutions. Considering all of the subjects taught at upper secondary schools in 2015, 16.9\% of the teachers were from Type A institutions, while $83.1 \%$ were educated at Type B institutions. For lower secondary school teachers, $37.4 \%$ graduated from Type A institutions, and $62.6 \%$ from Type B institutions (Ministry of Education, 2015). Clearly, the majority of secondary (lower and upper) school science teachers graduated from Type B institutions; therefore, they might only receive the minimum credits for professional studies necessary to become teachers.

Due to these differences, antagonism between different models for teacher education might persist to some extent, with professionalism being the focus of Type A institutions and academism the emphasis in Type B institutions. Ever since teacher education in Japan was organized during the late nineteenth century, there have been debates about the ideal model for secondary school teacher education, and where and how they should be educated. One of the ways to resolve this issue might be found in perspectives that focus on the significance of teachers' knowledge.

\section{Systematized in-service teacher education}

The Ministry of Education, prefectural boards of education, municipal boards of education, schools, and learned societies have provided frequent, varied in-service teacher education programs since WWII. Some of these programs are compulsory for in-service teacher education, are continually offered from the first to the last year, and are systematic as well as multi-dimensional.

The Ministry of Education took many bold initiatives for science education involving in-service teacher education between the 1950s and 1970s. For example, the Science Education Promotion Law was enacted in 1953, under which the Science Education Council was established as part of the Ministry of Education; from the mid-1950s to the 1960s, this council often prepared proposals and reports on how to promote science education. As a result, after 1960, general education and/or science education centers were established around the country to provide in-service teacher education programs, with financial assistance from the Ministry of Education (Ministry of Education, 1980; Morikawa, 1970). These centers had three functions: (1) provide in-service teacher education programs; (2) facilitate research in science teaching; and (3) disseminate ideas and research results through publications. Moreover, the Ministry of Education founded the Science Education Centre in 1972 as part of the National Institution for Educational Research (now called the National Institution for Educational Policy Research). The center organized an effective network, the National Science Education Centre Council, and held meetings, which included presentations of science teachers' research and practice, discussions, and exchanges of information on science education (Isozaki, 2016; Morikawa, 1970). 
As noted above, these facts exemplify Oshima's (1920) three prerequisites for effective science teaching. These activities remain a useful aspect of continuing professional development for science teachers.

\section{Current reforms in teacher education}

The two principles of teacher education have been in place for more than half a century. In the late 1970s and 1980s, several issues in education, some related to teachers, arose and gradually became social issues of national concern (e.g., Ota, 2011; Shimahara, 2002): kounai-bouryoku (school violence), and ijime (bullying) peaked in secondary schools. Gakkyü-houkai (classrooms in a state of crisis) were seen in elementary schools in the 1990s. Student absenteeism was also identified as an area of concern. Additionally, children as well as their parents began to be relatively less respectful toward teachers because many parents had graduated from universities just like the teachers. Therefore, the social status previously enjoyed by teachers has declined. These problems became social issues, "when the teaching profession itself was in question" (Ota, 2011, p. 50). Collins (1989) observed that the curriculum framework of pre-service teacher education recommended by the Ministry of Education (Tables 1 and 2), the emphasis on teaching subjects, and the relatively small amount of requirements for professional studies caused a "great deal of controversy" (p. 223). These facts about the changing teacher education system illustrate that pre-service teacher education is influenced by social context.

Based on the advice of several education councils in the Cabinet and the Ministry of Education, the Ministry of Education began to reform teacher and children's education continuously from the 1980s. These reforms were also a response to changes in society, children's social environments, and the conditions of children's education. These measures can be summarized as follows: (1) enhanced professional studies in teacher education programs; (2) new post-graduate courses with reorganized master courses offered at Type A institutions; and (3) a teacher certificate renewal system. These measures addressed virtually every aspect of teacher education and teacher certificates. Tables 1 and 2 show the pre-service teacher education curriculum of professional studies required by the Ministry of Education, focusing on secondary school science teachers (not elementary school teachers). The elementary school teacher is known as a homeroom teacher in Japan and instructs students in all subjects (such as science, mathematics, and home economics). Therefore, in pre-service teacher education, prospective teachers who become elementary school teachers must acquire content/ subject matter knowledge and teaching methods for every elementary school subject, while secondary school science teachers need to only study science.

Shulman (1987) categorized teacher knowledge as follows: (1) content knowledge; (2) general pedagogical knowledge; (3) curriculum knowledge; (4) pedagogical content knowledge (PCK); (5) knowledge of learners and their characteristics; (6) knowledge of educational contexts; and (7) knowledge of educational ends. The pre-service teacher education curriculum includes all aspects of a teacher's knowledge base.

The first category of subjects (Table 2) comprises subjects that encourage a sense of mission and responsibility, as well as a passion for education. As shown in Table 1, however, the minimum requirement for "teaching subjects," which is the same as Shulman's content/subject matter knowledge, has been significantly reduced since 
1998. Science prospective teachers must take the following subjects to gain content/ subject matter knowledge: physics, chemistry, biology, and earth science; all of these scientific subjects include lectures as well as practical work involving information and communication technology (ICT). These subjects are intended for certificates sought by lower and upper secondary school science teachers.

Japanese teachers are expected to gradually develop practical competencies in teaching. Consequently, current pre-service teacher education has placed greater emphasis on practical competencies based on professional studies, and less emphasis on research theories that support teaching and learning science (such as principles of science teaching and content/subject matter knowledge). The subjects under "Method of teaching subjects" are related to teaching science. The Faculty of Education at Hiroshima University (a Type A institution) offers the subject "General principles and methods of science teaching." It is compulsory to obtain a certificate to teach science in lower and upper secondary schools. This includes knowing why and what to teach in science, understanding how to teach science, how to assess students' performance based on research results, and solving real problems in science lessons. Additionally, the Faculty of Education at Hiroshima University provides instruction on other subjects related to the "Method of teaching subjects." For example, the subject "Science curriculum" covers the organizing and management of science curricula and knowledge, as well as understanding the course of study (similar to the national curriculum). The subject, "Seminar on science teaching" focuses on PCK by engaging prospective science teachers in researching and developing teaching materials (kyouzai-kenkyü), as well as making lesson plans (gakushü-shidouan sakusei) (Isozaki \& Ochi, 2017).

Every Type A national universities now have professional schools for post-graduate programs in teacher education. The goal of these programs is to enhance prospective teachers' professional specializations and to improve current teachers' teaching competencies and knowledge base through in-service teacher education. Professional schools' curricular focus on professional studies and practical application (e.g., case studies and/or action research) rather than theory. Furthermore, the Ministry of Education introduced a teacher certificate renewal system. Every certificate is valid for ten years and must be renewed after a decade by taking courses offered at Type A and Type B institutions and/or prefectural boards of education. These reforms seem to be based on ideas related to the model of professionalism. In this context, the main requirements for secondary school teachers have shifted from developing a knowledge base to acquiring teaching competencies.

Teachers' continuing professional development has historically been supported by the contributions of learned societies to the professional community, and teachers' voluntary self-improvement, and the government's efforts. However, since the 1980s, the conservative government's efforts to improve teacher education through laws and regulations have gradually increased and exerted pressure on teachers. TALIS 2013 (OECD, 2014) found that Japanese teachers spent more time in school compared to teachers in other countries. Therefore, Japanese teachers' professional culture, particularly lesson study, which is based on collegiality in the professional community, reached a turning point in the 1980s (Sato, 2011). 


\section{Discussion - Future challenges: A historical angle}

In Western countries, the James Report, created by the UK government (Department of Education and Science, 1972), and the Holmes Group Report, sponsored by the US Department of Education (Holmes Group, 1990), proposed modern teacher education systems (from pre-service through in-service education) in order to maintain continuity and consistency among professionals. When teacher education in Japan is compared with the recommendations of these reports, a problem emerges: both Type A and B institutions are responsible for pre-service teacher education, whereas in-service teacher education is mostly provided by prefectural and municipal boards of education and individual schools, and depends on teachers' voluntary self-improvement in professional communities. In Japan, pre-service teacher education has never been identified as the beginning of a cohesive process of continuous professional development. Ota (2011) argued that the link between pre-service and in-service education has been "very weak" (p. 44). Consequently, an important question arises: How does a novice teacher - regardless of his or her Type A or Type B education - become an expert science teacher?

The results of TALIS 2013 (OECD, 2014) indicated that Japanese teachers have higher than average participation rates in continuing professional development in terms of observational visits to other schools, which comprised 51\% compared to the TALIS average of 19\%. Ogawa (2014), Isozaki (2016), and Isozaki and Ochi (2017) noted that one reason for this difference might be Japan's professional culture, along with Japanese teachers' high level of enthusiasm. This also reflects an implicit consensus among teachers that even experts learn from others and should continue to improve their knowledge base and teaching competencies throughout their professional lives.

Japanese science teachers learn about the theoretical and practical aspects of teacher knowledge during their pre-service teacher education. However, quality and quantity vary, depending on the teacher education institutions and teaching staff. This means that there is no professional standard for the teaching profession, except the curriculum framework shown in Tables 1 and 2. This is unlike other countries. For example, the US has the National Board of Professional Standards and the UK has the Qualified Teacher Status and Teachers' Standards. Therefore, every teacher education institution in Japan should have an ideal model for the kind of teachers it wants to educate, such as reflective practitioners (Schön, 1983). Kobayashi (1993) argues that "professionalism should be founded on a base of rigorous academic discipline” (p. 13). A teacher's knowledge base should include content or scholarly knowledge of appropriate quantity and quality for teaching. In other words, institutions should clearly state their policies and philosophies on teacher education from the perspective of continuing professional development, because prospective teachers must continue to learn after being teachers, and formally and informally participate in in-service teacher education programs.

Science teachers who graduate Type A and Type B institutions seem to be in less conflict with each other now than before WWII. Hence, even if several teacher education reforms were implemented and the professional culture transformed, educators as well as politicians who design the teacher education system would consider the historical and socio-cultural aporia between the ideal model of the secondary school science teacher, and the entity that provides pre-service and in-service education. 


\section{Conclusion}

To compare pre-service science teacher education across the world, Lederman and Lederman (2015) asked readers the following question: "What is an appropriate balance of subject matter and pedagogy?" (p. 6). Similarly, Hirano and Pedersen (2017) argued that the question "What kind and how much teacher knowledge is needed for teacher qualified persons?' is difficult to answer" (p. 324; italics in original). In the East Asian Five countries, there are similarities in terms of the training model and courses; however, there is a conflict regarding the integration and balance between pedagogical knowledge and content/subject matter knowledge (Wang, et al., 2016). This problem is commonly observed not only in the West, but also in Asian countries and throughout the decades. As previously discussed, Japan is no exception. While the Japanese government - like other countries, and under the influence of social and political contexts - has taken steps to develop pre-service teacher education since the mid-nineteenth century, science teachers have historically established professional learning communities, and enthusiastically built a professional culture, to respond to these issues. Therefore, in this paper, the author identified this problem as "a historical and socio-cultural aporia." Future research should consider other obstacles regarding the development of teacher knowledge and the stages of a teacher's career.

As Ogawa (2014) and Isozaki (2016) maintained, this means that overemphasis on the Western approach to teacher education might lead to misunderstanding, and we should not ignore science teachers' wisdom and expertise, gained through their enthusiasm and reflective practices as part of the professional culture in our own country. Therefore, we should examine the practices that science teachers have developed as voluntary aspects of their professional culture, in order to reconsider science teacher education for the future. Additionally, it is necessary to think about how to develop science teachers' knowledge base (starting in pre-service teacher education) for continuing professional development.

This historical study concludes that it is important to continually reform teacher education based on reflections on research results and teachers' voices, and not for political reasons. However, it is also critical to identify the role that the professional learning community plays in aiding prospective teachers to become proficient and expert science teachers. These professional learning communities ensure professional standards in teaching by ensuring consistency and continuity of teacher education.

\footnotetext{
Author's contributions

The author read and approved the final manuscript.

Competing interests

The author declares that he has no competing interests.
}

\section{Publisher's Note}

Springer Nature remains neutral with regard to jurisdictional claims in published maps and institutional affiliations. 
Department of Education and Science. (1972). Teacher education and training: Report by a committee of inquiry appointed by the secretary of state for education and science, under the chairmanship of Lord James of Rusholme. London, UK: Her Majesty's Stationery Office.

Ferguson, P. (1985). Teacher education in Japan: An historical and comparative perspective. Journal of Teacher Education, 36(5), 20-24.

Green, A. (1997). Educational achievement in centralized and decentralized systems. In A. H. Halsey, H. Lauder, P. Brown \& A. S. Wells (Eds.). Education: Culture, economy, and society (pp. 283-298). Oxford, UK: Oxford University Press.

Hirano, T., \& Pedersen, J. E. (2017). International comparison of science teacher preparation: Various challenges in different contexts. In J. E. Pedersen, T. Isozaki, \& T. Hirano (Eds.), Model science teacher preparation programs: An international comparison of what works (pp. 307-325). Charlotte, NC: Information Age Publishing.

Holmes Group. (1990). Tomorrow's schools: Principles for the design of professional development schools. East Lansing, Ml: Holmes Group.

Inoue, H. (1975). The historical background and reforms of teacher training. Education in Japan, VIII, 69-83.

International Association for the Evaluation of Educational Achievement (IEA) (2016). TIMSS 2015 International Results in Science Chestnut Hill, MA: Boston College. (Retrieved from http://timss2015.org/download-center/(8_1_scienceteachers-formal-education-grade-8.pdf: Exhibit 8.2:Teachers'FormalEducation, http://timss2015.org/downloadcenter/(8_1_science-teachers-formal-education-grade-4.pdf:Exhibit 8.1:Teachers'FormalEducation)).

Isozaki, T. (2014). The organization and the recontextualisation of Rika (school science) education in the second half of the nineteenth century in Japan. Science \& Education, 23(5), 1153-1168.

Isozaki, T. (2015). Lesson Study research and practice in classroom. In R. Gunstone (Ed.), Encyclopedia of science education (pp. 615-618). Dordrecht, The Netherlands: Springer Reference.

Isozaki, T. (2016). How have Japanese rika (school science) teachers traditionally formed their own cultures and improved their teaching competencies through research and practice? In M.-H. Chiu (Ed.), Science education research and practice in Asia: Challenges and opportunities (pp. 517-538). Singapore: Springer.

Isozaki, T. (2017). Laboratory work as a teaching method: A historical case study of the institutionalization of laboratory science in Japan. Espacio, Tiempo y Educación (Journal of History of Education, Spain), 4(2), 101-120.

Isozaki, T., \& Isozaki, T. (2011). Why do teachers as a profession engage in lesson study as an essential part of their continuing professional development in Japan? International Journal of Curriculum Development and Practice, 13(1), 31-40.

Isozaki, T., \& Ochi, T. (2017). Secondary science teacher education/training in Japan. In J. Pedersen, T. Isozaki, \& T. Hirano (Eds.), Model science teacher preparation programs: An international comparison of what works (pp. 287-306). Charlotte, NC: Information Age Publishing.

Kimura, H., \& Iwata, Y. (2007). The historical trend of teacher identity in Japan: Focusing on educational reforms and the occupational culture of teachers. Hitotsubashi Journal of Social Studies, 39, 19-42.

Kobayashi, T. (1993). Japan's teacher education in comparative perspectives. Peabody Journal of Education, 68(3), 4-14.

Kumura, T., \& Iwahashi, B. (1967). Development of the teacher training system in Japan. Education in Japan, II, 75-89.

Lederman, N. G., \& Lederman, J. S. (2015). The status of preservice science teacher education: A global perspective. Journal of Science Teacher Education, 26(1), 1-6.

Ministry of Education, Culture, Sports, Science and Technology (2015). Gakko-kyōin tōkei-chōsa (statistics data of school teachers) [in Japanese]. Tokyo, Japan: Ministry of Internal Affairs and Communications. (Retrieved from http://www. e-stat.go.jp/SG1/estat/List.do?bid=000001058722\&cycode=0)

Ministry of Education, Culture, Sports, Science and Technology (2017). Monbukagaku-shourei (The Ministry of Education Order), No. 41 [in Japanese]. (Retrieved from http://www.mext.go.jp/b_menu/hakusho/nc/_icsFiles/afieldfile/2017/ 11/30/1398706_2_1.pdf.)

Ministry of Education, Culture, Sports, Science and Technology (n. d.). Kyouikushokuin menkyohou sekoukisoku (The regulation of school teachers certificates) [in Japanese]. (Retrieved from http://www.mext.go.jp/a_menu/koutou/ kyoin/1268593.htm.)

Ministry of Education, Science and Culture. (1980). Japan's modern educational system: A history of the first hundred years. Tokyo, Japan: Ministry of Finance.

Miyoshi, N. (1979). Controversial problems of teacher education in Japan: From a comparative historical viewpoint. Education in Japan, IX, 27-41.

Morikawa, H. (1970). Science education center. In The Japanese National Commission for UNESCO (Ed.), Training of science teachers in Japan: Present and future (pp. 164-190). Tokyo, Japan: Ministry of Education, Science and Culture.

Ogawa, M. (2014). Occupational cultures as means of professional development for preservice science teachers in Japan. In C. Y. Lin \& R.-J. Wang (Eds.), Innovations in science teacher education in the Asia Pacific (pp. 61-80). Bingley, UK: Emerald Publishers.

Ogawa, M. (2015). Rika. In R. Gunstone (Ed.), Encyclopedia of Science Education (p. 840). Dordrecht, The Netherlands: Springer Reference.

Organisation for Economic Co-operation and Development (2014). Results from TALIS 2013, Country note: Japan. Paris: OECD. (Retrieved from http://www.oecd.org/japan/TALIS-2013-country-note-Japan.pdf.)

Oshima, C. (1920). Rika-kyoujyu no genri (The principles of science teaching) [in Japanese]. Tokyo, Japan: Dōbunkan.

Ota, N. (2011). Teacher education and its reform in contemporary Japan. International Studies in Sociology of Education, 10(1), 43-60.

Sansom, G. B. (1968). The western world and Japan: A study in the interaction of European and Asiatic cultures. New York, US: Alfred A. Knopf

Sato, M. (1999). Kindai nihon kyouin kenshü-shi kenkyü (A study on history of in-service teacher education in modern Japan) [in Japanese]. Tokyo, Japan: Kazamashobo.

Sato, M. (2011). Trend of reform: Contemporary innovation of lesson study. In The National Association for Study of Educational Methods (Ed.), Lesson Study in Japan (pp. 142-150). Hiroshima, Japan: Keishusha.

Schön, D. A. (1983). The reflective practitioner: How professionals think in action. New York, US: Basic Books.

Scott, M. M. (1884). Education in Japan. The Hawaiian Monthly, 1(11), 253-257. (Retrieved from https:/books.google.co.jp/ books?id=vLYX_8gCXq0C\&printsec=frontcover\&hl=ja\&source=gbs_ge_summary_r\&cad=0\#v=onepage\&q\&f=false.) 
Shimahara, N. K. (1998). The Japanese model of professional development: Teaching as craft. Teaching and Teacher Education, 14(5), 451-462.

Shimahara, N. K. (2002). Teaching in Japan: A cultural perspective. New York, US: Routledge.

Shulman, L. S. (1987). Knowledge and teaching: Foundations of the new reform. Harvard Educational Review, 57(1), 1-22.

Tokuhiro, T. (1970). Training systems for science teachers. In The Japanese National Commission for UNESCO (Ed.), Training of science teachers in Japan: Present and future (pp. 139-150). Tokyo, Japan: Ministry of Education, Science and Culture.

Tokyo University of Arts and Sciences. (1931). Souritsu rokujyu-nen (Founding sixty years) [in Japanese]. Tokyo, Japan: Towa-insatsu.

Wang, L., Cheung, D., Chiu, M.-H., Ogawa, M., \& Park, Y.-S. (2016). Pre-service education of high school science teachers. In H.-S. Lin, J. K. Gilbert, \& C.-J. Lien (Eds.), Science education research and practice in East Asia: Trends and perspectives (pp. 273-302). Taipei, Taiwan: Higher Educational Publishing.

Watanabe, Y. (2012). Kyoushi seisaku ni okeru "kyouiku no riron" no seishitu no henka (The nature of changes on "theory of education" in educational policies), Bulletin of Centre for Research and Development of Education, Fukushima University [in Japanese], 13, 39-46.

Submit your manuscript to a SpringerOpen ${ }^{\oplus}$ journal and benefit from:

- Convenient online submission

- Rigorous peer review

Open access: articles freely available online

High visibility within the field

Retaining the copyright to your article

Submit your next manuscript at $\gg$ springeropen.com 